THURSDAY, APRIL 6, I87I

\section{THE UTILISATION OF NATURAL HISTORY MUSEUMS FOR SCIENTIFIC INSTRUCTION IN GERMANY}

$\mathrm{T}$ the following notes we propose to consider the Natural History Museums in Germany, and to see to what extent and in what manner, indirect or direct, they are utilised for the scientific instruction or education of the people. These institutions are very numerous, there being one in nearly every larger German town, and even two or three in places like Vienna and Hamburg. Some comprise collections of zoological, anatomical, palæontological, botanical, and mineralogical objects, while others are limited to one or more of these branches, but whatever their contents may be, we do not recollect visiting one of these Museums in which the objects were left unnamed or unarranged. The majority are State establishments, under the direction of a single head, who is responsible to the Minister of Public Instruction. If the establishment is very extensive, the collections of the various branches are placed under more than one director, the administration and responsibilities being divided. Their development is in some measure dependent on the direct assistance of the Government, but still more on the energy and capability of the director, inasmuch as, of two Museums originally supported by the same grant of money, one has remained stationary for years, whilst the director of the other, making the best use of his independent position, has known how to raise the value of his Museum as a purely scientific or instructive institution, thus establishing claims for additional assistance, which could not be neglected by the Government.

We may divide the German Museums into-(I) Those founded with the intention of exhibiting objects of Natural History to the general public; and (2) those established for educational purposes.

There are not many of the former class. To it belong the Museums of the formerly independent "Reichsstädte," Hamburg, Bremen, and Frankfort-on-the-Main, one of the Vienna Museums, and the collections in Stuttgart and Darmstadt. There are others, like that in Mayence, but they have more the character of well-arranged local country museums. Although originally founded for the purpose of exhibiting curiosities, they soon took another position by receiving objects in which the general public takes a very limited interest (as, for instance, botanical, geological, or mineralogical specimens), and by systematically collecting materials for the purposes of purely scientific research. In several instances the scientific results were sufficiently important and extensive to form not only a nucleus but the sole subject-matter of distinct periodical works, such as the "Annalen des Wiener Museums," the "Museum Senckenbergianum," the "Abhandlungen des Hamburger Museums." The Frankfort Museum became the head-quarters for the Zoology of North-eastern Africa ; Bremen possesses a unique collection of African birds, celebrated not only for the great number of standard specimens, but also for their beautiful state of preservation. In the Vienna Museum particular attention was paid to European fresh-water fishes; and travellers like Natterer, Russeger, Kotschy, enriched it with collections so numerous that the Austrian Naturalists have been engaged in their examination till within a very recent period. The Stuttgart and Darmstadt Museums are now celebrated for their valuable collections of South-German fossils, worked out by G. von Jäger, Kaup, and others.

In the Museums of this class great attention is paid to the local Flora and Fauna, recent and extinct. Thus the Stuttgart collection may be mentioned as a model of what a Museum ought to be ; besides a most complete series of the plants and fossils, it contains a collection of the animals of Suabia in all stages of growth and development and of variation, in a perfect state of preservation, and particularly attractive from the life-like manner in which the specimens are mounted.

It was the natural consequence of the growth of a Museum, especially in the smaller of the towns mentioned, that it became a conspicuous object; that, although opened to the general public on certain hours of Sunday only, the crowds of visitors increased; that the interest in it spread into wider circles; and that, more or less in connection with it, societies were formed whose aim was the distribution of knowledge, and which were accessible to all. Although no great benefit is individually derived by the majority of the members of such societies from their rather superficial connection with Science, yet we ought to remember that even the fragments of knowledge picked up by them have the effect of expanding their ideas. A community of feeling grows up between the professed naturalist and the uninitiated, by which the former is encouraged in his further pursuits, and induced to consult in his labours and communications the requirements and understanding of the latter. Some of the German Governments, especially the Austrian, have also acknowledged the value of such societies by granting them an annual subsidy.

One out of several instances may be brought forward in evidence of the correctness of the above remarks, viz. the example of the town of Frarkfort, to which many years ago a small miscellaneous collection and library was bequeathed, under the name of "Museum Senckenbergianum." By the able management and disinterestedness of Dr. Eduard Rüppell, it grew into a considerable zoological collection, of which the inhabitants were justly proud. An interest in Natural History being awakened, a body of men, chiefly wealthy merchants, formed themselves into a society, founding a Zoological Garden, and in connection with it a monthly periodical (noticed in one of our previous numbers), in which, at first, only objects of local interest were discussed, but which now has among its contributors eminent naturalists as well as amateurs, and does more for the distribution of sound natural history knowledge among the general German public than all the other scientific periodicals put together.

While thus we fully acknowledge the value of the Museums of this class as offering materials for really scientific original research, and as creating and maintaining an interest in Science among the general public, we understand that they are not utilised in a direct manner for methodical scientific instruction. Although Natural History is taught in nearly all the so-called Gymnasiums and Polytechnic Schools; the time devoted to it is limited, and those Museums are only visited at intervals by the classes under the guidance of teachers. 